9-2005

\title{
Hyperpycnal Discharge of Fluvial Sediment to the Ocean: Impact of Super-Typhoon Herb (1996) on Taiwanese Rivers
}

John D. Milliman

Virginia Institute of Marine Science

Shuh-Ji Kao

Virginia Institute

Follow this and additional works at: https://scholarworks.wm.edu/vimsarticles

Part of the Geology Commons

\section{Recommended Citation}

Milliman, John D. and Kao, Shuh-Ji, "Hyperpycnal Discharge of Fluvial Sediment to the Ocean: Impact of Super-Typhoon Herb (1996) on Taiwanese Rivers" (2005). VIMS Articles. 1823.

https://scholarworks.wm.edu/vimsarticles/1823

This Article is brought to you for free and open access by the Virginia Institute of Marine Science at W\&M ScholarWorks. It has been accepted for inclusion in VIMS Articles by an authorized administrator of W\&M ScholarWorks. For more information, please contact scholarworks@wm.edu. 


\title{
ARTICLES
}

\section{Hyperpycnal Discharge of Fluvial Sediment to the Ocean: Impact of Super-Typhoon Herb (1996) on Taiwanese Rivers}

\author{
John D. Milliman and Shuh-Ji Kao \\ School of Marine Science, College of William and Mary, Gloucester Point, Virginia 23062, U.S.A. \\ (e-mail: milliman@vims.edu)
}

\begin{abstract}
A B S T R A C T
Hyperpycnal events (when suspended sediment concentrations exceed $40 \mathrm{~g} / \mathrm{L}$ ) occur in small- and medium-sized rivers throughout the world but are particularly common in Taiwan; they are often related to landslides or debris flows initiated and transported by typhoon floods. Super-Typhoon Herb, which swept across Taiwan on July 31-August 2, 1996, triggered floods and landslides throughout the southern part of the island. Sediment concentrations in at least seven rivers (Taan, Choshui, Pachang, Erhjen, Tsengwen, Kaoping, and Peinan) approached or exceeded 40 g/L. Calculated sediment discharged from nine rivers (these seven as well as the $\mathrm{Wu}$ and Houlung, neither of which apparently reached hyperpycnal concentrations) during these $3 \mathrm{~d}$ was 217 million tons (MT) - most of it on August 1—of which $\sim 80 \%$ was discharged at hyperpycnal concentrations. Presumably, most of the sediments discharged by the Peinan River (to the southeast) and the Kaoping, Erhjen, Tsengwen, and Pachang rivers (to the southwest) were transported directly to the Huatong Basin and the South China Sea (via the Penghu Canyon system), respectively. The bulk of the typhoon-derived sediment (142 MT), however, was discharged to the northwest (primarily by the Choshui River), and its fate remains unknown. It may have ultimately reached the Penghu Canyon system and thereby the South China Sea, but more probably it was transported northward (via the Taiwan Warm Current) toward China, the East China Sea, or (perhaps) the Okinawa Trough.
\end{abstract}

\section{Introduction}

Hyperpycnal Flow. Hyperpycnal flows are defined as negatively buoyant fluvial discharges resulting from high concentrations of suspended sediment (Mulder and Syvitski 1995, modified from Bates 1953) that are denser than the oceanic waters into which they are discharged. On the basis of water temperature and the salinity of oceanic coastal waters, fluvial waters with sediment concentrations of $\sim 36-43 \mathrm{~g} / \mathrm{L}$ will produce hyperpycnal flows (Mulder and Syvitski 1995, their table 1), although laboratory experiments suggest that concentrations as dilute as $1 \mathrm{~g} / \mathrm{L}$ may effect a hyperpycnal flow (Parsons et al. 2001). For the purposes of this article, we define hyperpycnal flows as containing at least $40 \mathrm{~g} / \mathrm{L}$ of suspended sediment; mixing with saline water may permit more dilute concentrations to attain negative buoyancy.

Manuscript received July 7, 2004; accepted March 4, 2005.

${ }^{1}$ Research Center for Environmental Change, Academia Sinica, Taipei, Taiwan.
Using the mean annual fluvial discharge and sediment loads in Milliman and Syvitski's (1992) 280river database, Mulder and Syvitski (1995) identified nine "dirty rivers," which they defined as having mean annual sediment concentrations $>10 \mathrm{~g} / \mathrm{L}$ : the Huanghe, Daling, and Haihe (China); Choshui, Tsengwen, and Erhjen (Taiwan); Dier and Isser (Algeria); and Rioni (Russia). According to Mulder and Syvitski (1995), these rivers must reach hyperpycnal levels regularly. Using Mulder and Syvitski's (1995) criteria and expanding the database to $\sim 600$ rivers (J. D. Milliman and K. L. Farnsworth, unpub. data) add another six rivers to the dirty river list: the Agroun (Algeria), Draa and Massa (Morocco), Hualien (China), Semani (Albania), and Santa Maria (southern California). Mulder and Syvitski (1995) also listed a number of rivers that may produce hyperpycnal plumes at least once every $100 \mathrm{yr}$ in response to maximum possible flooding events, including an additional 15 Taiwanese rivers. 
Taken together, these data suggest that hyperpycnal events can occur in a wide range of smallto medium-sized rivers, ranging from freshwater runoff of $<100 \mathrm{~mm} / \mathrm{yr}$ (Huanghe and Santa Maria River) to more than $2000 \mathrm{~mm} / \mathrm{yr}$ (Choshui River). Taiwanese rivers appear particularly likely to experience hyperpycnal events (Chen et al. 2004). Recently, S. Dadson, N. Hovius, S. Pegg, W. B. Dade, and M.-J. Horng (unpub. data) have calculated that $30 \%-42 \%$ of the cumulative Taiwanese river sediment load between 1970 and 1999 was delivered at hyperpycnal concentrations.

One problem in using annual hydrological data to document the occurrence and magnitude of hyperpycnal flows is that most events are short lived, so even daily sampling of the river may not capture a turbid flow and almost certainly not its magnitude. If shorter durations (hours rather than days) are considered (e.g., Syvitski 2003; Hicks et al. 2004), hyperpycnal events are much more common and occur in more rivers than commonly believed.
The importance of close-interval sampling in documenting hyperpycnal events was illustrated by the hourly monitoring of a number of southern California rivers during two major storms in 1969 (Waananen 1969). In the Santa Clara River (4100$\mathrm{km}^{2}$ watershed just north of Los Angeles), for example, peak rainfall near the headwaters reached $20 \mathrm{~mm} / \mathrm{h}$ during the midmorning of January 25 . Discharge and suspended sediment concentrations quickly responded, reaching maximum sediment concentrations and sediment loads exceeding 150 $\mathrm{g} / \mathrm{L}$ and 2.5 million tons $(\mathrm{MT}) / \mathrm{h}$, respectively, 4-5 $\mathrm{h}$ after the peak rainfall. Most of the sediment transported during this storm (15 MT-roughly equal to the Santa Clara's cumulative load for the previous $20 \mathrm{yr}$ ) was discharged in $\sim 7 \mathrm{~h}$ at concentrations $\geq 100 \mathrm{~g} / \mathrm{L}$ (Waananen 1969). The importance of hyperpycnal events in southern California rivers can be seen by the fact that between 1950 and 1999 they represented only $\sim 0.1 \%$ of the cumulative time but accounted for $40 \%-75 \%$ of the

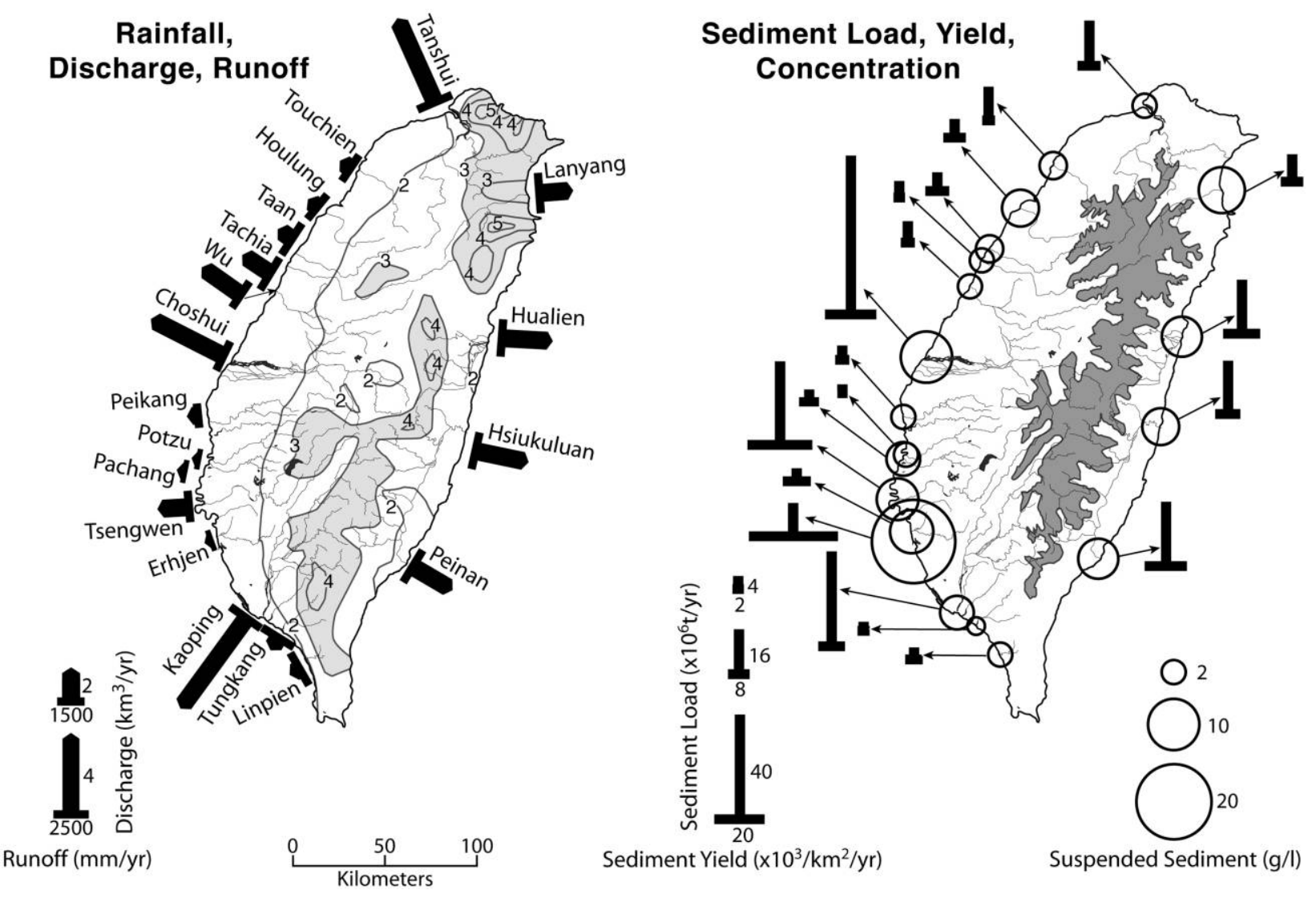

Figure 1. Left, major rivers draining Taiwan showing mean annual discharge (vertical bars) and runoff (horizontal bars). Mean annual rainfall ( $\mathrm{m} / \mathrm{yr})$ is portrayed as isohyets, $>3 \mathrm{~m} / \mathrm{yr}$ shaded. Right, sediment discharge from Taiwanese rivers showing mean annual sediment load (vertical bars), sediment yield (horizontal bars), and suspended sediment concentration (circles). Shaded area represents elevations $>1000 \mathrm{~m}$. Data from WRA (1997). 
various rivers' total sediment loads (Warrick and Milliman 2003).

Fate of Hyperpycnal Flows. On reaching the coastal ocean, hyperpycnal flows should sink beneath the less dense surface waters and, depending on the magnitude of river discharge, the subbottom morphology/gradient, and oceanic conditions, may escape seaward of the littoral cell (Warrick and Milliman 2003). An excellent example of the plunging sediment-laden plume is shown in an aerial photograph taken off southern Iceland after a Jokulhlaup (glacial flood) in 1996 (photograph by M. T. Gumundsson and F. Palsson, http://www.hi.is/ mmh/gos, fig. 3 in Mulder et al. 2003) in which a muddy plume is surrounded by clear water, suggesting that the edge of the plume is plunging beneath the less dense surface waters.

During a major flood on December 22-23, 1964, the Eel River (northern California) had daily mean suspended sediment concentrations of 30 and $35 \mathrm{~g} /$ L, respectively (Waananen et al. 1970); following the Santa Clara example, short-term sediment concentrations in the Eel must have been considerably greater. The fate of the $\sim 100 \mathrm{MT}$ of sediment discharged during this 2-d flood is not clear, but the presence of what appears to be an event-related unconformity on the mid-outer shelf (Sommerfield and Nittrouer 1999) suggests that most of the transported sediment may have bypassed the shelf, perhaps being deposited on the adjacent continental slope (N. Driscoll, pers. comm., 2003). The seaward escape of hyperpycnal flows is also evidenced by the above-mentioned 1969 southern California flood during which fluvial sediment was transported to the outer margins of the Santa Barbara shelf and into the Santa Barbara Basin (Drake et al. 1972; Gorsline 1996).

In this article, we discuss the response of Taiwanese rivers to Super-Typhoon Herb, during which >200 MT of sediment, most of it at hyperpycnal concentrations, was discharged to the coastal ocean in little more than $1 \mathrm{~d}$. The immediate and ultimate fates of this sediment, however, remain points of speculation.

\section{Taiwan Rivers}

The island of Taiwan lies in the collision path between the Philippine and Asian plates, resulting in mountain uplift of 5-7 mm/yr (Liu 1982). The combination of high elevations in the Central (Mountain) Range (locally approaching $4000 \mathrm{~m}$ ) and soft, erodable rocks (particularly in the southern foothills west of the Central Range), together with frequent earthquakes and periodically heavy rainfall, result in particularly rapid rates of denudation $(\mathrm{Li}$ 1976). Dadson et al. (2003) have concluded that the cumulative seismic moment release and temporal variability in runoff (particularly during typhoonrelated floods) are the dominant erosional controls in Taiwan. Although anthropogenic impact on the Taiwan landscape is difficult to quantify, Kao and Liu (2002, their fig. 5b) have shown that more than $80 \%$ of the Lanyang River (northeast corner of the island) post-1958 sediment load resulted from human activities within the watershed, namely, road building, urbanization, and expanded agriculture.

As a result of this environmental setting, the rivers draining Taiwan are well known for their high runoff, their highly turbid waters, and their exceptionally high sediment yields (Li 1976). The 21 rivers listed in the Hydrologic Yearbook of the Water Resources Agency (WRA) of Taiwan drain a cumulative basin area of $24,500 \mathrm{~km}^{2}$, only four of which (Wu, Tanshui, Choshui, and Kaoping) have watersheds larger than $2000 \mathrm{~km}^{2}$. Rainfall across Taiwan generally averages more than $2000 \mathrm{~mm} / \mathrm{yr}$ and can exceed $4000 \mathrm{~mm} / \mathrm{yr}$ in the mountains (fig. 1 , left). Fluvial discharge and runoff range from 0.8 to $7 \mathrm{~km}^{3} / \mathrm{yr}$ and 1300 to $2800 \mathrm{~mm} / \mathrm{yr}$, respectively, with eastern rivers tending to have greater runoff by virtue of intense rainfall in the mountains (fig. 1, left).

The 21 rivers cited in the WRA hydrologic yearbooks are listed as discharging a total of $260 \mathrm{MT}$

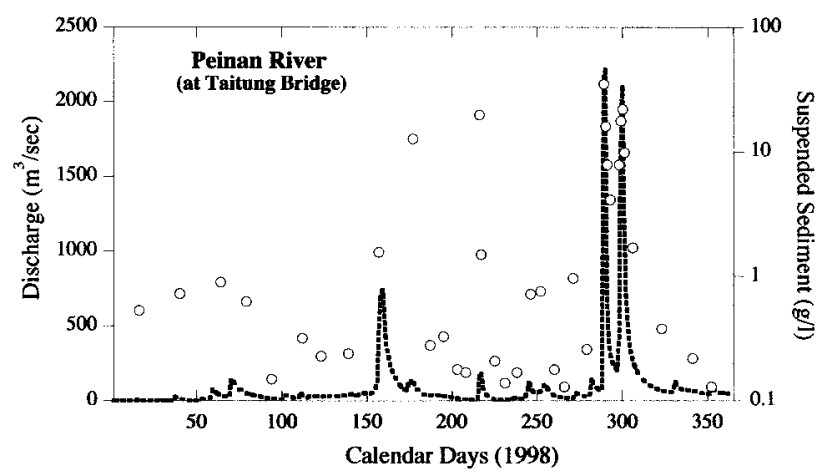

Figure 2. Daily discharge (dashed line) and suspended sediment concentrations (circles) of the Peinan River (measured at Taitung Bridge) in 1998. The discharge scale is linear, whereas the sediment concentrations are logarithmic. Highest discharges (2230 and $2110 \mathrm{~m}^{3} / \mathrm{s}$ ) and sediment concentrations $(22-35 \mathrm{~g} / \mathrm{L})$ were recorded in mid-October during Typhoons Zeb and Babs. Other turbid concentrations appear unrelated to discharge; a concentration of $12.7 \mathrm{~g} / \mathrm{L}$ on June 4 , for example, occurred when the discharge was only $136 \mathrm{~m}^{3} / \mathrm{s}$. Data from WRA (1997). 

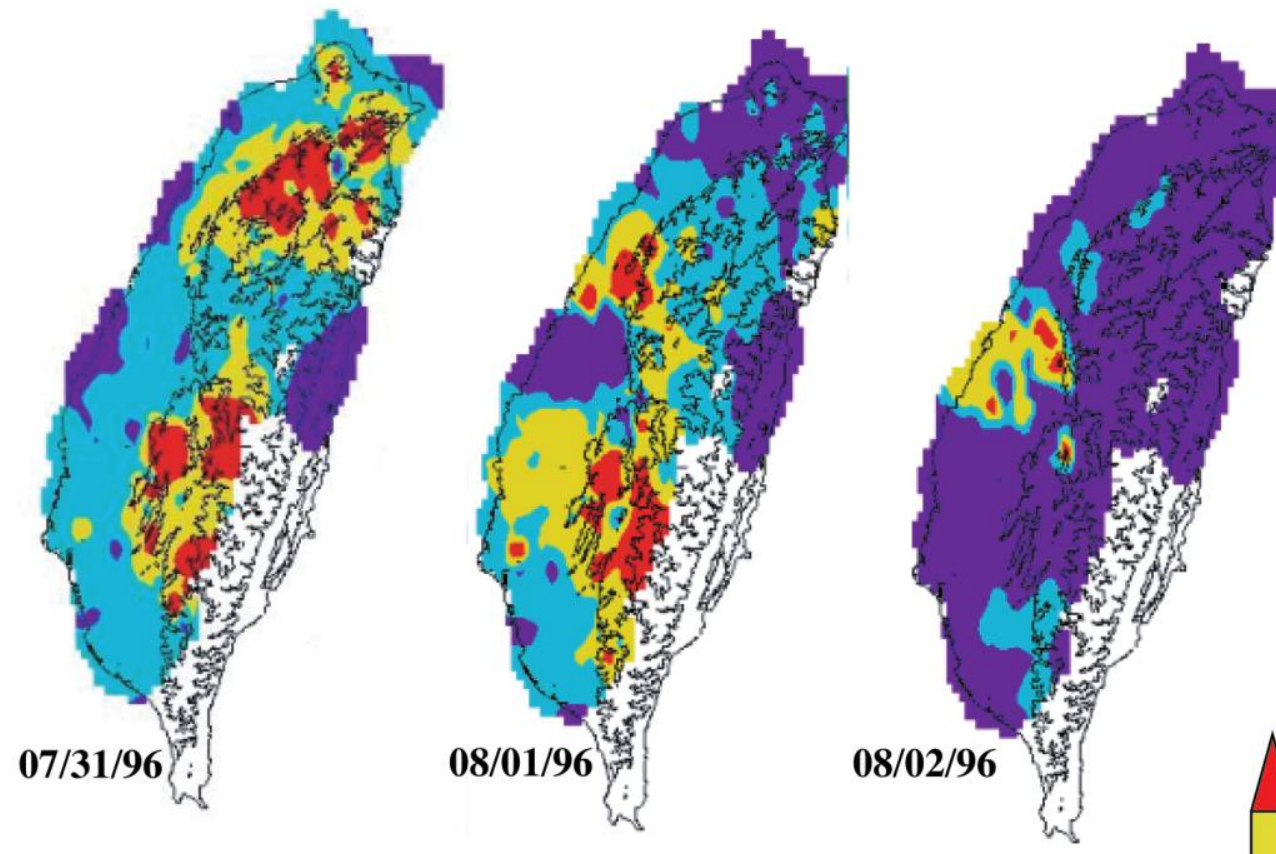

Daily Precipitation $(\mathbf{m m} / \mathrm{day})$

400

200

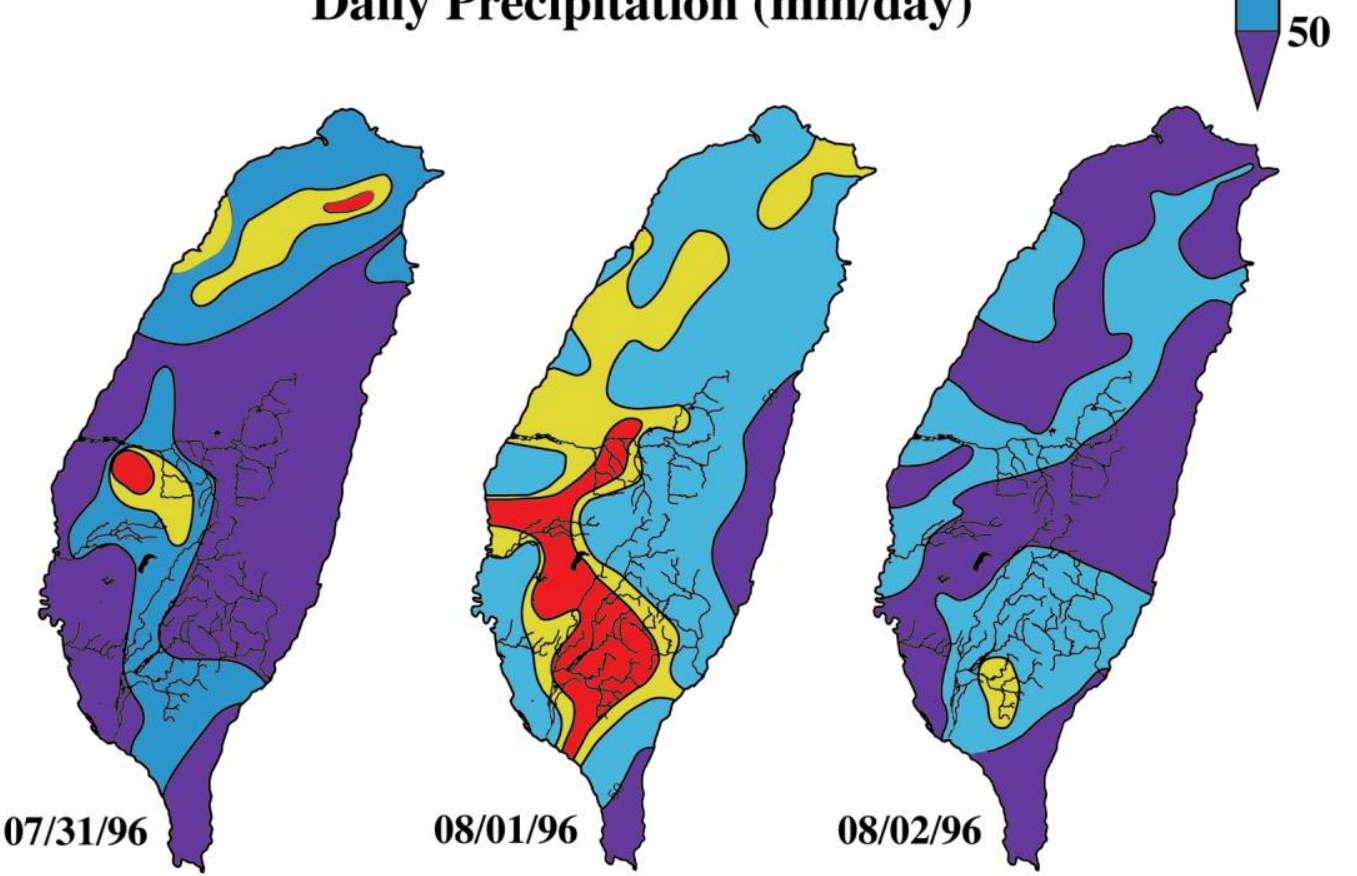

Daily Runoff (mm/day)

Figure 3. Top, daily precipitation (mm/d) over Taiwan, July 31-August 2, 1996, based on rain gauge measurements made at 226 meteorological stations. Lack of sufficient data prevents plotting isohyets over the southeastern part of the island. Bottom, daily fluvial runoff $(\mathrm{mm})$ of Taiwanese rivers, July 31-August 2, 1996, based on data from 133 hydrologic stations (data from WRA 1997). 
of sediment annually, which equates to a mean sediment yield of nearly $11,000 \mathrm{t} / \mathrm{km}^{2} / \mathrm{yr}$. (Mean annual sediment loads calculated by Dadson et al. [2003] diverge somewhat from the WRA numbers, the greatest discrepancy being the Peinan River, which they calculate to be $88 \mathrm{MT} / \mathrm{yr}$ compared with the WRA's $24 \mathrm{MT} / \mathrm{yr}$. Dadson et al. estimate that the annual suspended discharge from Taiwan is $380 \mathrm{MT} / \mathrm{yr}$; including bed load, they estimate total sediment discharge at $500 \mathrm{MT} / \mathrm{yr}$.) Six rivers are listed in the WRA yearbooks as having mean annual sediment loads $\geq 20 \mathrm{MT} / \mathrm{yr}$ (Choshui, Kaoping, Tsenwen, Peinan, Hualien, Hsiukuluan), and several rivers have sediment yields exceeding $20,000 \mathrm{t} / \mathrm{km}^{2} / \mathrm{yr}$ (fig. 1, right), which equates to a basin-wide erosion rate of $\sim 8 \mathrm{~mm} / \mathrm{yr}$. Because much of the sediment ultimately comes from the uplands and mountains, local denudation must exceed 10 $\mathrm{mm} / \mathrm{yr}$.

In general, the highest sediment loads and yields occur in rivers that drain the central and southern mountains (fig. 1, right), where the lithology is dominated by fine-grained sedimentary rocks. The
Choshui River (3150- $\mathrm{km}^{2}$ drainage basin area) is listed by the WRA as having a mean annual sediment load of $64 \mathrm{MT}$, which equates to a sediment yield of $\sim 20,000 \mathrm{t} / \mathrm{km}^{2} / \mathrm{yr}$ and an average annual suspended sediment concentration of $\sim 10 \mathrm{~g} / \mathrm{L}$. Even relatively "clean" Taiwanese rivers are sediment laden. The WRA yearbooks cite the Tungkang River $\left(472 \mathrm{~km}^{2}\right.$, in the southwestern part of the island) as having a sediment yield of $\sim 1300 \mathrm{t} / \mathrm{km}^{2} /$ $\mathrm{yr}$ and an average suspended sediment concentration of "only" $\sim 1 \mathrm{~g} / \mathrm{L}$. The Amazon, Mississippi, and Yangtze rivers, by comparison, have mean annual sediment yields and concentrations of 160,60 , and $270 \mathrm{t} / \mathrm{km}^{2} / \mathrm{yr}$ and $0.16,0.43$, and $0.52 \mathrm{~g} / \mathrm{L}$, respectively.

River flow in Taiwan is highly seasonal, with most rain falling between June and October. Discharge of most rivers during drier months averages $<10-50 \mathrm{~m}^{3} / \mathrm{s}$, whereas during rainy months, it can exceed $1000-5000 \mathrm{~m}^{3} / \mathrm{s}$. Episodes of very high discharge are often associated with typhoons, whose floods are characterized by an abrupt rise and fall of discharge, the entire event often lasting only a
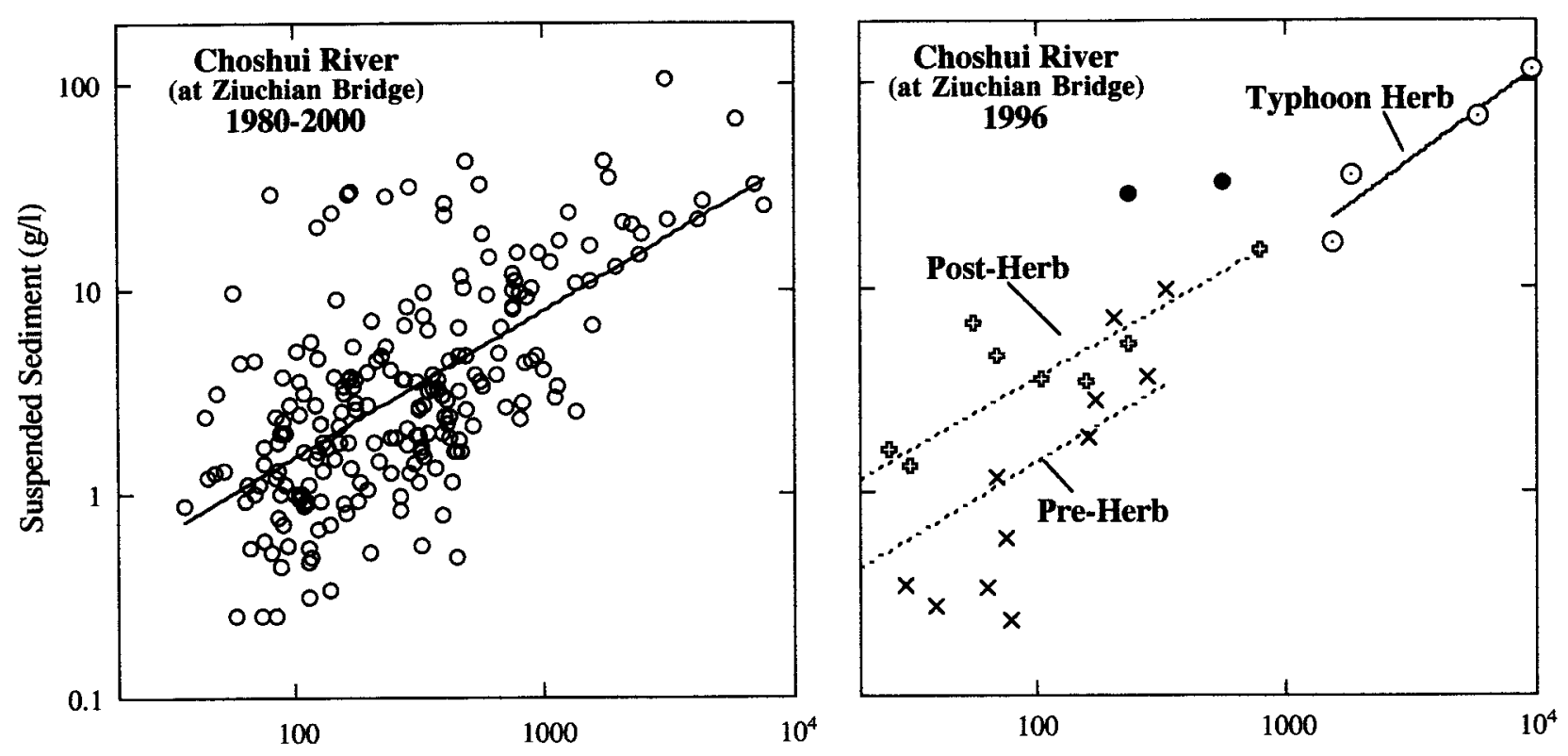

Discharge (cms)

Figure 4. Left, relation between measured discharge and suspended sediment concentrations in the Choshui River, 1990-1998. Any particular discharge can produce a two to three orders of magnitude range in suspended sediment concentrations. The low $R^{2}$ value (0.37) of the algorithm underlines the impracticality of using such a sedimentrating curve. Right, sediment-rating curve for the Choshui River based on 1996 data. Note that three distinct curvesbefore, during, and after Typhoon Herb—suggest counterclockwise hysteresis. The $R^{2}$ of the four measurements taken during Typhoon Herb is 0.95 and predicts closely the two highest measured values (see figs. 5, 6). Two anomalously high concentrations (solid dots) appear to be in response to Typhoon Gloria, which occurred several days before Herb. 


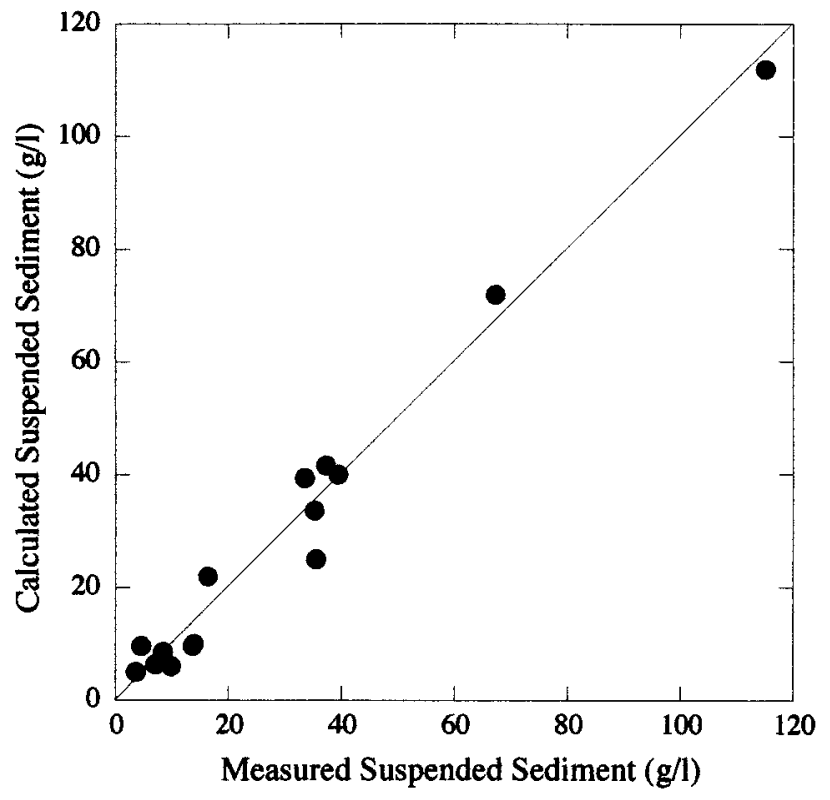

Figure 5. Sediment concentrations in the Choshui, Pachang, Erhjen, Kaoping, and Peinan rivers measured by the WRA during and immediately following Typhoon Herb (July 31-August 5) compared with sediment concentrations calculated from rating curves based on discharge and measured sediment data. Because low concentrations coincided with low discharges, sediment transport would have been extremely small; we therefore compare only concentrations $>5 \mathrm{~g} / \mathrm{L}$.

few days. In 1998, except for a few weeks in midJune, flow in the Peinan River, located in the southeast part of the island (fig. 1, left), did not exceed $100 \mathrm{~m}^{3} / \mathrm{s}$, and measured suspended sediment concentrations were generally $<1 \mathrm{~g} / \mathrm{L}$ (fig. 2). In October, however, Typhoons Zeb and Babs elevated Peinan discharge to $\sim 5000 \mathrm{~m}^{3} / \mathrm{s}$ and sediment concentrations exceeding $20 \mathrm{~g} / \mathrm{L}$.

\section{Hyperpycnal Events in Taiwanese Rivers}

As a consequence of the natural setting and the impact from human activities, landslides in Taiwan tend to be frequent, primarily related to meteorological events and occasional earthquakes (Hovius et al. 2000; Hartshorn et al. 2002; Fuller et al. 2003; Dadson et al. 2004). Turbid flows, most of which are derived directly or indirectly from landslides (see, e.g., Hovius et al. 1997, 2000; Dadson et al. 2004), also are frequent, many of them apparently unrelated to river discharge. High concentrations of suspended sediment in Taiwanese rivers, in fact, can occur during both low and high flow. In the Peinan River example, elevated sediment concen- trations in 1998 were measured during low flow as well as during Typhoons Zeb and Babs (fig. 2).

Some of the high-concentration/low-discharge occurrences in Taiwanese rivers are related to human activities. Road construction in the southwestern part of the island in 1990, for example, apparently contributed to some of the highest sediment concentrations ever reported for any river: $484 \mathrm{~g} / \mathrm{L}$ in the Erhjen on August 21 and $615 \mathrm{~g} / \mathrm{L}$ in a tributary of the Tsengwen on September 10 (WRA
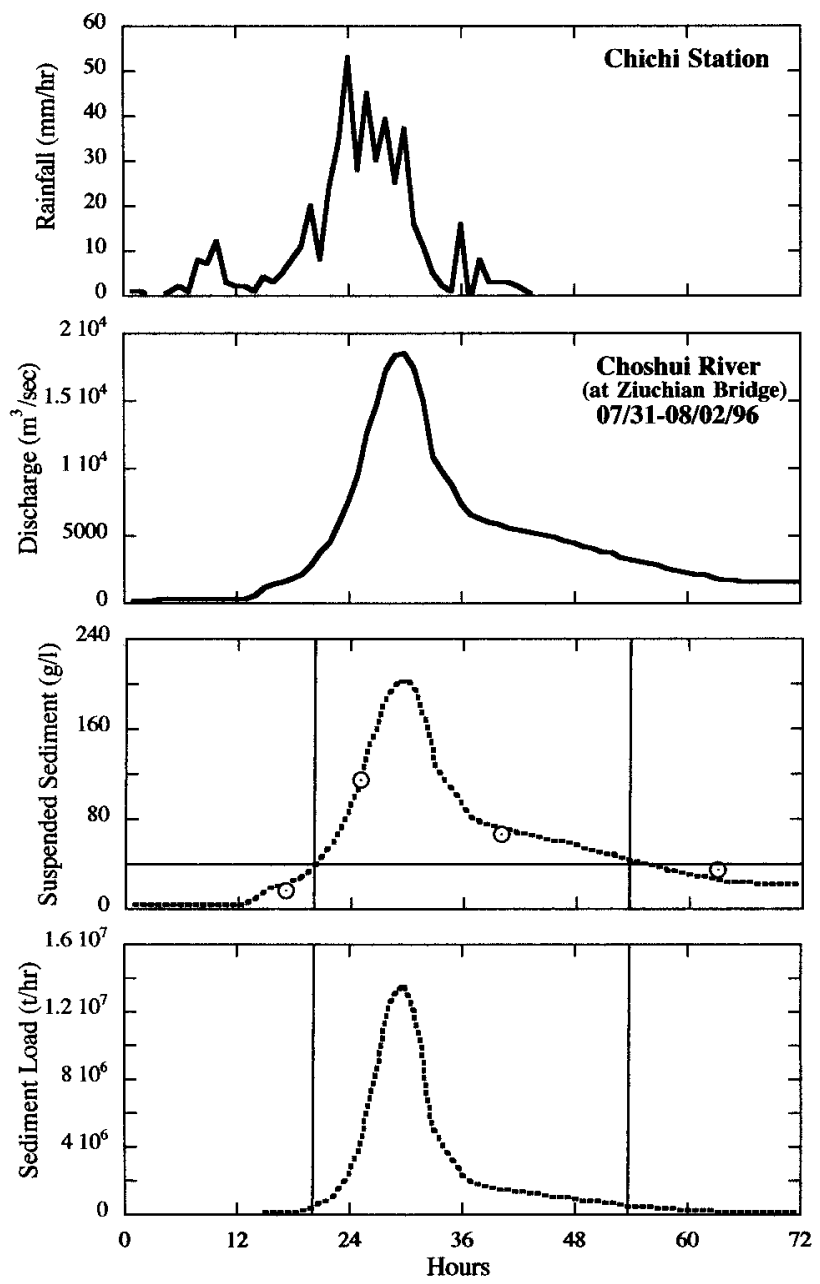

Figure 6. Top, hourly rainfall at Chichi meteorological station, near the headwaters of the Choshui River, July 31-August 2, 1996. Discharge based on hourly measurements (second from top), calculated suspended sediment concentrations (second from bottom), and calculated hourly sediment load (bottom) for the Choshui River at Ziuchian Bridge (upstream basin area $2989 \mathrm{~km}^{2}$; total drainage basin area $3155 \mathrm{~km}^{2}$. Circles represent measured suspended sediment concentrations, and vertical lines represent the period during which concentrations were hyperpycnal. Data from WRA (1997). 

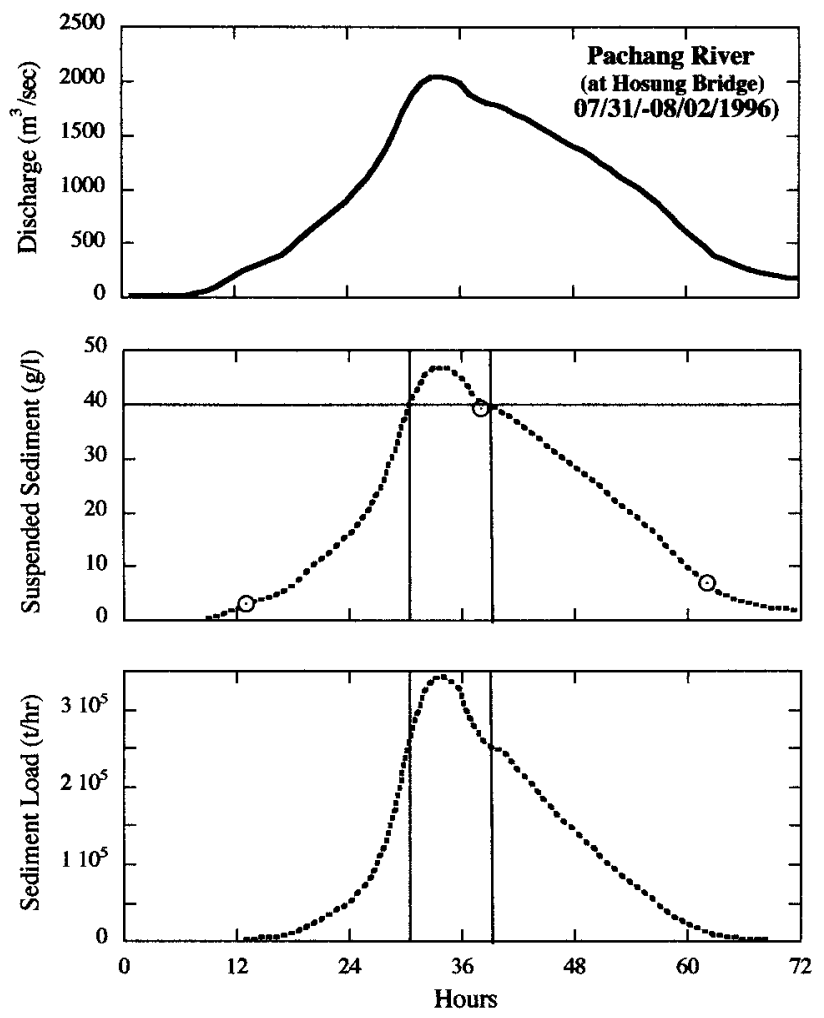

Figure 7. Discharge based on hourly measurements (top), calculated suspended sediment concentrations (middle), and calculated hourly sediment load (bottom) for the Pachang River at Hosung Bridge (upstream basin area $441 \mathrm{~km}^{2}$; total drainage basin area $474 \mathrm{~km}^{2}$ ), July 31-August 2, 1996. Circles represent measured suspended sediment concentrations. Data from WRA (1997).

1992, pp. 196, 198). The Liwu River (central east coast, not shown in fig. 1) is not included the WRA 21 key rivers, but between 1978 and 1983, 13 measured concentrations exceeded $20 \mathrm{~g} / \mathrm{L}$, whereas between 1983 and 1997, no high concentrations were reported. In 1997 and 1998, however, measured concentrations again periodically exceeded $20 \mathrm{~g} / \mathrm{L}$, suggesting that the two separate periods of hyperpycnal flow may have been related to land use change within the drainage basin.

Between 1978 and 1998, the WRA yearbooks list more than 100 occurrences on 11 Taiwanese rivers in which measured sediment concentrations exceeded $20 \mathrm{~g} / \mathrm{L}$. The Erhjen River had the most-43 reported events (in $15 \mathrm{yr}$ )-followed by the Peinan (26 yr), Lanyang (15 yr), and Choshui (8 yr). A recent calculation by S. Dadson, N. Hovius, S. Pegg, W. B. Dade, and M.-J. Horng (unpub. data) ranks the Erhjen, Choshui, and Peinan as the most likely to attain hyperpycnal levels. Because most Taiwanese rivers are undersampled, however, the number of hyperpycnal events in Taiwanese rivers unquestionably is much greater than evidenced in the WRA database.

\section{Super-Typhoon Herb: July 31-August 2, 1996}

Genesis and History. In 1996, 43 tropical cyclones developed in the northwest Pacific; 20 were classified as typhoons, of which six were supertyphoons (wind speeds $>140 \mathrm{kn}$ ). In late July 1996, Super-Typhoon Herb tracked over the northern Philippine Sea in a general northwest direction. By early July 31 , Herb was located about $300 \mathrm{~km}$ east of Taiwan. It then changed to a more westerly course, reaching landfall on northeastern Taiwan in the early afternoon, with wind speeds exceeding $130 \mathrm{kn}$. By early evening, the eye of Herb had crossed Taiwan and was headed toward southern China, which it reached early the next morning (August 1). By then, peak wind speeds had dropped to $95 \mathrm{kn}$.

By many accounts, Herb was the worst storm to hit Taiwan in $30 \mathrm{yr}$, leaving 44 dead and another 20 missing. Total damage amounted to more than $\$ 500$ million. As is true with most hurricanes and typhoons, much of the damage resulted from heavy rains and related flash floods rather than strong winds. Rainfall was particularly heavy in the mountains, exceeding $400 \mathrm{~mm} / \mathrm{d}$ in both the northern and southern parts of the island on July 31 (fig. 3 , upper left). By August 1, as the storm moved over southern China, the heavy rains had shifted to the southwest, and by August 2, only the central-western parts of the island experienced daily rainfall exceeding $50 \mathrm{~mm}$ (fig. 3, upper right). Total rainfall during Herb in the Central Range locally exceeded $1800 \mathrm{~mm}$ (Hung 1996; Wu and Kuo 1999), and the Mount Ali weather station recorded rainfall exceeding $80 \mathrm{~mm} / \mathrm{h}$ for 14 consecutive hours (Wu and Kuo 1999).

Fluvial runoff resulting from Herb varied spatially and temporally. Daily runoff in much of the eastern part of the island reached or exceeded 50 $\mathrm{mm} / \mathrm{d}$ only on August 1. In northeastern and central-western parts of the island, runoff on July 31 locally surpassed $200 \mathrm{~mm}$, and on August 1, runoff exceeded $400 \mathrm{~mm} / \mathrm{d}$ throughout many of the southwestern watersheds (fig. 3, bottom). Instantaneous and daily discharges on the Kaoping and Choshui rivers surpassed historic peaks, with the peak discharge of the Kaoping reaching $19,700 \mathrm{~m}^{3} / \mathrm{s}$ on August 1. By August 2, runoff had slackened considerably, although some parts of the southwest corner 
Table 1. Calculated Sediment Loads for Nine Taiwanese Rivers Resulting from Typhoon Herb, July 31-August 2, 1996

\begin{tabular}{|c|c|c|c|}
\hline River (gauging station) & $\begin{array}{l}\text { Calculated load } \\
\times 10^{6} \mathrm{t}\end{array}$ & $\begin{array}{c}\text { Load }>40 \mathrm{~g} / \mathrm{L} \\
\times 10^{6} \mathrm{t}(\%)\end{array}$ & $\begin{array}{c}\text { Load }>30 \mathrm{~g} / \mathrm{L} \\
\times 10^{6} \mathrm{t}(\%)\end{array}$ \\
\hline \multicolumn{4}{|l|}{ Southeast: } \\
\hline Peinan (Taitung Bridge) & 11 & $8(72)$ & $8.6(78)$ \\
\hline \multicolumn{4}{|l|}{ Southwest: } \\
\hline Pachang (Hosung Bridge) & 6.5 & $2.5(38)$ & $4.8(74)$ \\
\hline Tsengwen (Mashan Bridge) & 8.6 & $5.8(67)$ & $7.2(84)$ \\
\hline Erhjen (Alien-2) & 1.4 & $0(0)$ & $1.3(86)$ \\
\hline Kaoping (Lilin Bridge) & 48 & $26(56)$ & $37(80)$ \\
\hline \multicolumn{4}{|l|}{ Central/northwest: } \\
\hline Houlong (Peishih Bridge) & 1.8 & $0(0)$ & $0(0)$ \\
\hline Taan (Ili) & 7.4 & $3.4(45)$ & $5.0(65)$ \\
\hline Wu (Tatu Bridge) & 2.8 & $0(0)$ & $0(0)$ \\
\hline Choshui (Ziuchian Bridge) & 130 & $125(96)$ & $127(98)$ \\
\hline Total & 217 & $171(80)$ & $190.9(93)$ \\
\hline
\end{tabular}

of the island still experienced $200 \mathrm{~mm} / \mathrm{d}$ (fig. 3, bottom).

Herb's Effect on Sediment Discharge from Taiwanese Rivers. Although there apparently was no islandwide census of typhoon-initiated landslides ( $\mathrm{N}$. Hovius, pers. comm., 2004), the heavy rains initiated substantial downslope mass movement, as witnessed by the 20 landslides along a $33-\mathrm{km}$ section of the new central cross-island highway (Lin et al. 1996). Aerial photographs along a $92-\mathrm{km}^{2}$ tributary to the Choshui River indicated 248 landslides covering a total area of 380 ha (Chang and Slaymaker 2002). Lee (1996, p. 22) reported a large number of landslides in Chenyulan Creek, another mountain tributary to the Choshui. One week after Herb, the WRA measured a sediment concentration of $26 \mathrm{~g} / \mathrm{L}$ on this creek; sediment concentrations clearly must have been much higher during peak runoff on July 31 and August 1.

On the basis of the data presented in the 1996 WRA yearbook, between late July and early August, measured suspended sediment concentrations exceeded $10 \mathrm{~g} / \mathrm{L}$ at the downstream hydrologic stations on five rivers (Choshui, Pachang, Erhjen, Kaoping, and Peinan), only two of which (Pachang and Erhjen) were monitored near peak discharge. Because of the infrequent sediment sampling, it is entirely possible that hyperpycnal levels were reached in several other rivers, most probably the Tsengwen and Taan.

Deriving sediment-rating curves for these rivers proved somewhat difficult given the relatively few suspended sediment measurements taken before, during, and after the storm. Long-term curves were of little use given the often one to two orders of magnitude variation in sediment concentration at any fixed discharge. The long-term rating curve of the Choshui, for example, has a coefficient of de- termination $\left(R^{2}\right)$ of only 0.37 (fig. 4, left). To alleviate this problem as well as to correct any bias in regression-based rating curves (e.g., Cohn 1995), we created event-based rating curves by partitioning the 1996 suspended sediment measurements (WRA 1997) into those taken before, during, and after Typhoon Herb. For the Choshui River, for example, measurements taken after Herb were generally substantially higher than those taken before July 31 (fig. 4, right).

Post-Herb concentrations remained relatively high, suggesting that landslides initiated during Herb provided an abundant sediment supply for the post-Herb flow. The Typhoon Herb rating curve for the Choshui was based on the four suspended sediment measurements taken between July 31 and August 2, the coefficient of determination being 0.95. For the other four rivers, similar event-based rating curves were constructed, although all were based on only three or four data points. Coefficients of determination for these rating curves were high-0.92-0.97-reflecting in part the few data used to construct the curves. The primary problem in using such rating curves to derive suspended sediment concentrations is that it assumes a direct relationship between concentration and discharge, thereby negating the possibility of short-lived hysteresis loops by which peak concentrations might precede or follow peak discharge. Unfortunately, only continuous sampling might detect such deviations (Hicks et al. 2004). The close agreement between calculated and measured sediment concentrations (e.g., 112 vs. 115 g/L for the Choshui River; fig. 5), however, suggests that our rating curves were sufficiently valid to minimize problems related to bias correction, which can dramatically underestimate actual sediment concentra- 

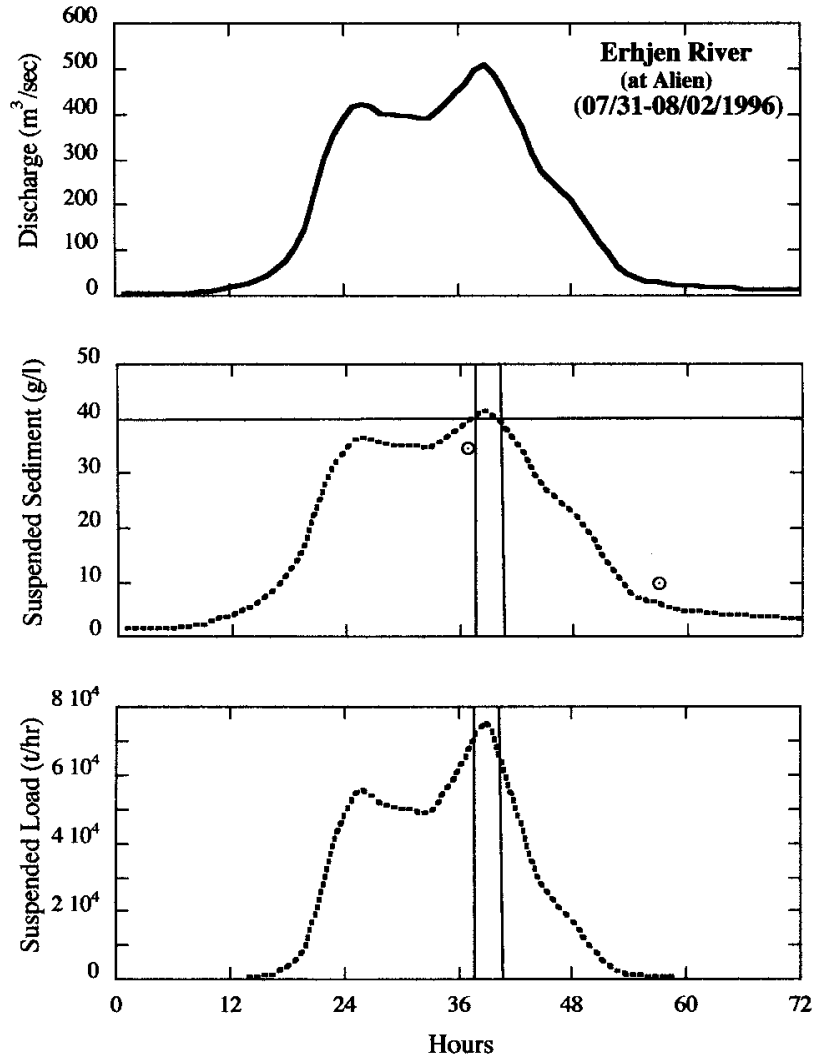

Figure 8. Discharge based on hourly measurements $($ top), calculated suspended sediment concentrations (middle), and calculated hourly sediment load (bottom) for the Erhjen River at Alien-2 (upstream basin area 175 $\mathrm{km}^{2}$; total drainage basin area $350 \mathrm{~km}^{2}$ ), July 31-August 2, 1996. Circles represent measured suspended sediment concentrations. Data from WRA (1997).

tions (Cohn 1995; Dadson et al. 2003). Using hourly discharges and derived sediment concentrations, we calculated hourly sediment loads, the results of which are shown in figures 6-10 and are discussed in the following paragraphs.

Rainfall at the Chichi meteorological station, near the headwaters of the Choshui River (and, ironically, near the epicenter of the Chichi earthquake $3 \mathrm{yr}$ later; Dadson et al. 2004) began early on July 31, increasing to $>25 \mathrm{~mm} / \mathrm{h}$ just before midnight and then dropping substantially by midmorning on August 1 (fig. 6). Flow on the Choshui (at the Ziuchian Bridge gauging station, $\sim 8 \mathrm{~km}$ from the Taiwan Strait) began to rise about midday on July 31 and peaked at $19,100 \mathrm{~m}^{3} / \mathrm{s}$ early the next morning, about $6 \mathrm{~h}$ after peak rainfall was recorded at Chichi (fig. 6). Flow first fell sharply and then more gradually to $2200 \mathrm{~m}^{3} / \mathrm{s}$ by noon on August 2. The highest calculated suspended sediment concentration (203 g/L) and sediment load $\left(13.5 \times 10^{6} \mathrm{t} / \mathrm{h}\right)$ occurred at 0600 hours on August 1 (fig. 6). Between midnight and noon on August 1, calculated sediment discharge was $90 \mathrm{MT}$, during which suspended sediment concentrations exceeded $100 \mathrm{~g} / \mathrm{L}$.

Discharge on the Pachang River displayed a much less dramatic response to Typhoon Herb. Rising at the Hosung Bridge gauging station, $6 \mathrm{~km}$ from the Taiwan Strait, at about 0800 hours on July 31, maximum flow $\left(\sim 2000 \mathrm{~m}^{3} / \mathrm{s}\right)$ was measured between 0800 and 1000 hours on August 1, after which it decreased gradually to $1400 \mathrm{~m}^{3} / \mathrm{s}$ by midnight and to $160 \mathrm{~m}^{3} / \mathrm{s}$ by the end of August 2 (fig. 7). The highest calculated suspended sediment concentration was $47 \mathrm{~g} / \mathrm{L}$ (midday August 1; fig. 7). Total sediment transported by the Pachang during the 3-d period was $6.5 \mathrm{MT}$, of which $\sim 38 \%$ was transported at concentrations $>40 \mathrm{~g} / \mathrm{L}$ (table 1).

Before the arrival of Herb, the Erhjen River, the
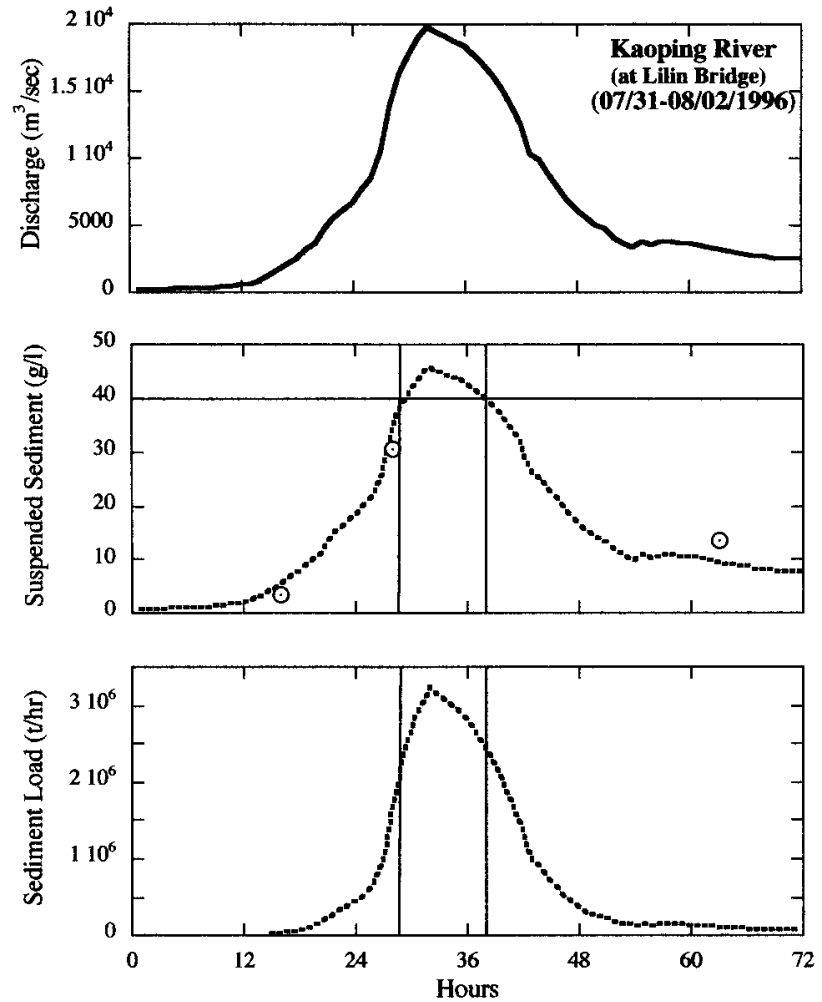

Figure 9. Discharge based on hourly measurements $(t o p)$, calculated suspended sediment concentrations (middle), and calculated hourly sediment load (bottom) for the Kaoping River at Lilin Bridge (upstream basin area $2895 \mathrm{~km}^{2}$; total drainage basin area $3257 \mathrm{~km}^{2}$ ), July 31August 2, 1996. Circles represent measured suspended sediment concentrations. Data from WRA (1997). 

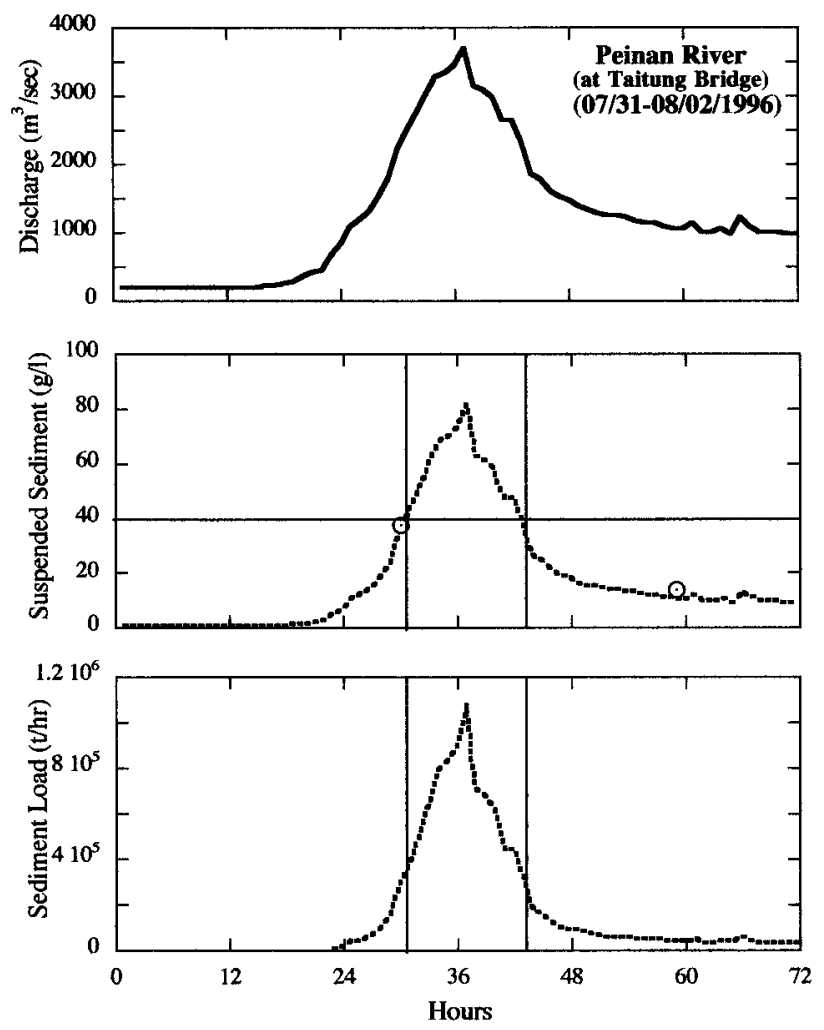

Figure 10. Discharge based on hourly measurements (top), calculated suspended sediment concentrations (middle), and calculated hourly sediment load (bottom) for the Peinan River at Taitung Bridge (upstream basin area $1584 \mathrm{~km}^{2}$; total drainage basin area $1603 \mathrm{~km}^{2}$ ), July 31-August 2, 1996. Circles represent measured suspended sediment concentrations. Data from WRA (1997).

smallest of the rivers discussed in this article (basin area $350 \mathrm{~km}^{2}$ ), was discharging only $\sim 4 \mathrm{~m}^{3} / \mathrm{s}$ at the Alien-2 gauging station, $15 \mathrm{~km}$ from the coast. By midnight on August 1, discharge had increased to $390 \mathrm{~m}^{3} / \mathrm{s}$. It peaked twice that afternoon, after which it dropped to $11 \mathrm{~m}^{3} / \mathrm{s}$ the following midnight (fig. 8). Although calculated suspended sediment concentrations barely reached $40 \mathrm{~g} / \mathrm{L}$, they exceeded $30 \mathrm{~g} / \mathrm{L}$ for nearly $24 \mathrm{~h}$, during which the river transported $\sim 1.3 \mathrm{MT}$. The low stream power and sediment loads in the Erhjen during Herb presumably reflect the small portion of the watershed drained by the high-rainfall mountains.

The largest river in Taiwan $\left(3257 \mathrm{~km}^{2}\right)$, with headwaters at $~ 4000-\mathrm{m}$ elevations, Kaoping River flow (at Lilin Bridge, $\sim 45 \mathrm{~km}$ from the coast) increased from $\sim 200 \mathrm{~m}^{3} / \mathrm{s}$ in the early morning of July 31 to $>19,000 \mathrm{~m}^{3} / \mathrm{s}$ between 0800 and 1000 hours on August 1. Discharge then decreased to $6140 \mathrm{~m}^{3} /$ $\mathrm{s}$ at midnight and $3570 \mathrm{~m}^{3} / \mathrm{s}$ the following noon (fig. 9). The close fit between the three observed sediment concentrations and the derived sedimentrating curve suggests that peak sediment concentration was probably no greater than $45 \mathrm{~g} / \mathrm{L}$, although concentrations exceeded $30 \mathrm{~g} / \mathrm{L}$ for $14 \mathrm{~h}$. Sediment transported during this 14 -h interval totaled $37 \mathrm{MT}, \sim 80 \%$ of the total event-driven load, but only $26 \%$ of the total calculated sediment load was at concentrations $>40 \mathrm{~g} / \mathrm{L}$ (fig. 9; table 1).

The Peinan River was the only east coast river that apparently reached hyperpycnal levels during Typhoon Herb. Flow at Taitung Bridge, $\sim 8 \mathrm{~km}$ from the Philippine Sea, peaked at $3690 \mathrm{~m}^{3} / \mathrm{s}$ just after noon on August 1 and then dropped abruptly to $1470 \mathrm{~m}^{3} / \mathrm{s}$ by midnight (fig. 10). Calculated sediment concentrations exceeded $40 \mathrm{~g} / \mathrm{L}$ for $12 \mathrm{~h}$ on August 1 (0700-1900 hours), during which the river discharged $\sim 8$ MT (fig. 10; table 1).

The lack of field measurements made during Herb prevented us from calculating the suspended loads for most other rivers in the southern part of the island, where the typhoon had greatest impact. However, rating curves based on measurements taken before and after Herb suggest that the Taan and Tsengwen rivers also experienced hyperpycnal flows. Using rating curves based on post-Herb data, we calculate that the sediment loads transported by these two rivers were 7.4 and 8.6 MT, respectively, of which 3.4 and 5.8 MT were at concentrations $>40 \mathrm{~g} / \mathrm{L}$. (We note that no suspended sediment measurements were taken on the Tsengwen

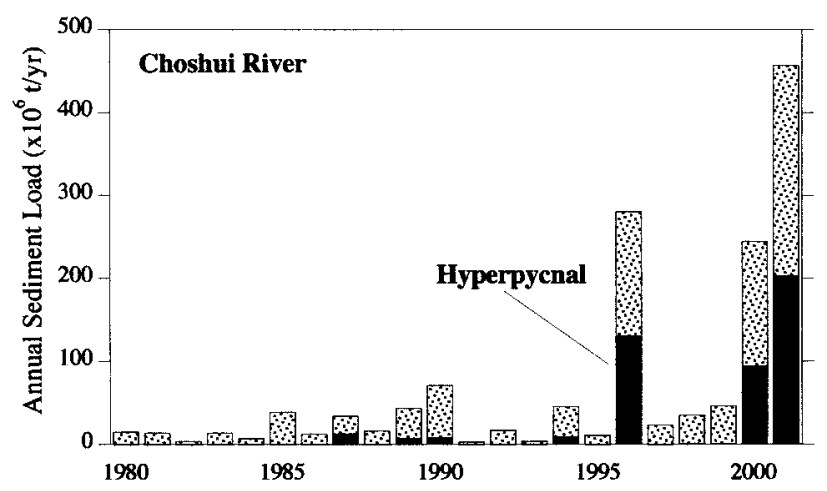

Figure 11. Calculated annual suspended loads for the Choshui River, 1980-2001, based on annual sedimentrating curves. The black portion of each bar represents the estimated amount discharged at hyperpycnal concentrations. The mean 1980-2001 load decreases by nearly $40 \%$ (42 to $26 \mathrm{MT} / \mathrm{yr}$ ) if the sediment loads derived from Typhoons Herb (1996) and Toraji and Nori (2001) are ignored, emphasizing the importance of the shortlived hyperpycnal events on this river. 


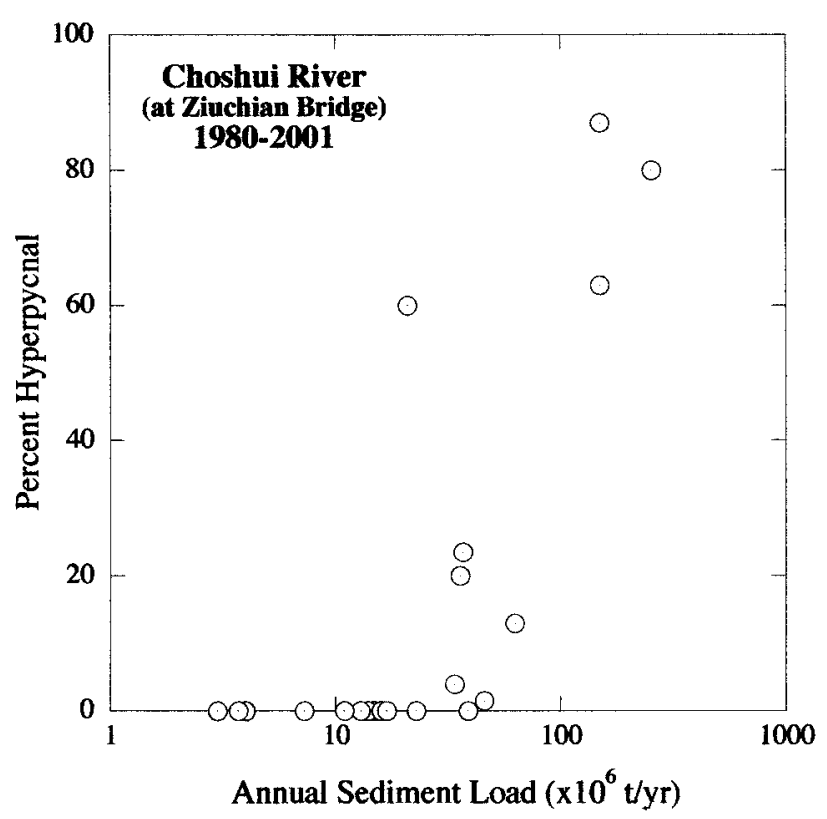

Figure 12. Percentage of annual loads represented by hyperpycnal flows in the Choshui River, 1980-2002. As with the Santa Clara River in southern California, years with low sediment loads are predominantly hypopycnal, whereas annual loads substantially greater than $\sim 50 \mathrm{MT}$ are delivered largely at hyperpycnal concentrations.

between July 31 and August 13, thus making any calculation of event-related sediment concentrations and loads particularly precarious.) Two other rivers, the $\mathrm{Wu}$ and Houlong, are calculated to have discharged significant amounts of sediment-1.8 and 1.0 MT, respectively-during the typhoon but apparently at hypopycnal, not hyperpycnal, levels. Presumably, the sediments discharged by other rivers were not elevated substantially above normal seasonal levels.

Collectively, the nine Taiwanese rivers are estimated to have discharged 217 MT of sediment to coastal waters during and immediately after Typhoon Herb (table 1), the bulk of this load being delivered between midnight and 1800 on August 1 . Collectively, the other Taiwanese rivers probably discharged no more than 5-10 MT during this same period. The 217-MT estimate represents approximately $80 \%$ of the total mean annual sediment load of the 21 largest Taiwanese rivers as listed by the WRA. In fact, the calculated Herb-derived sediment loads for the Choshui, Pachang, and Kaoping were substantially greater than their mean annual loads (see fig. 1). Approximately $80 \%$ of the Herb-induced sediment load was discharged at concentrations $>40 \mathrm{~g} / \mathrm{L}$ (table 1$)$. If we consider a less conservative lower boundary of hyperpycnal flow to be $30 \mathrm{~g} / \mathrm{L}$, which is entirely possible if the fluvial discharge sufficiently diluted the coastal waters, hyperpycnal concentrations would have accounted for nearly $90 \%$ of the cumulative load (table 1).

\section{Flux and Fate of the Hyperpycnal Discharge}

The importance of episodic hyperpycnal events in Taiwanese rivers can be shown by the example of the Choshui River. Using annual sediment-rating curves, many of which closely resemble the counterclockwise hysteresis curve in figure 4 (right), we calculate that between 1980 and 2001, the Choshui discharged approximately 970 MT of suspended sediment, of which about half (470 MT) was discharged at concentrations $>40 \mathrm{~g} / \mathrm{L}$ (fig. 11). The seven high-discharge events during this 22 -yr period (all of them primarily hyperpycnal) totaled $<30$ $\mathrm{d}(\sim 0.25 \%$ of the cumulative time), but the total sediment load transported amounted to more than half of the cumulative 22-yr sediment load.

In this respect, the prominence of episodic hyperpycnal sediment flux from the Choshui River is surprisingly similar to the Santa Clara River mentioned earlier in this article, even though the annual runoff of the two rivers differs greatly: $>2000$ versus $<50 \mathrm{~mm} / \mathrm{yr}$. Despite the markedly different hydrologic regimes, discharge on both rivers is event driven (fig. 12), the Santa Clara responding to El Niño-Southern Oscillation/Pacific Decadal Oscillation-related storms and the Choshui to typhoons. The importance of seasonal variations in rainfall and river flow in determining fluvial erosion and sediment transport from small mountainous rivers also has been noted in Indonesia (Cecil et al. 2003).

The fate of the sediment discharged during Typhoon Herb is not entirely clear. The southeastern shelf adjacent to the Peinan River is only a few kilometers wide, beyond which the steep slope drops into the $>4000-\mathrm{km}$-deep Huatong Basin (fig. 13). Given the narrow shelf, a direct bypass from the Peinan River to this deep basin, particularly during hyperpycnal flow, seems likely.

On the southwestern side of the island, the Kaoping River empties directly into the Kaoping Canyon, which feeds into the Penghu Canyon system, which in turn leads into the South China Sea. The mouths of the Erhjen, Tsengwen, and Pachang rivers also are relatively close to Penghu Canyon, and it therefore seems reasonable to assume that sediment discharged from all four rivers reaches this system and thereby ultimately the South China Sea (fig. 13). 


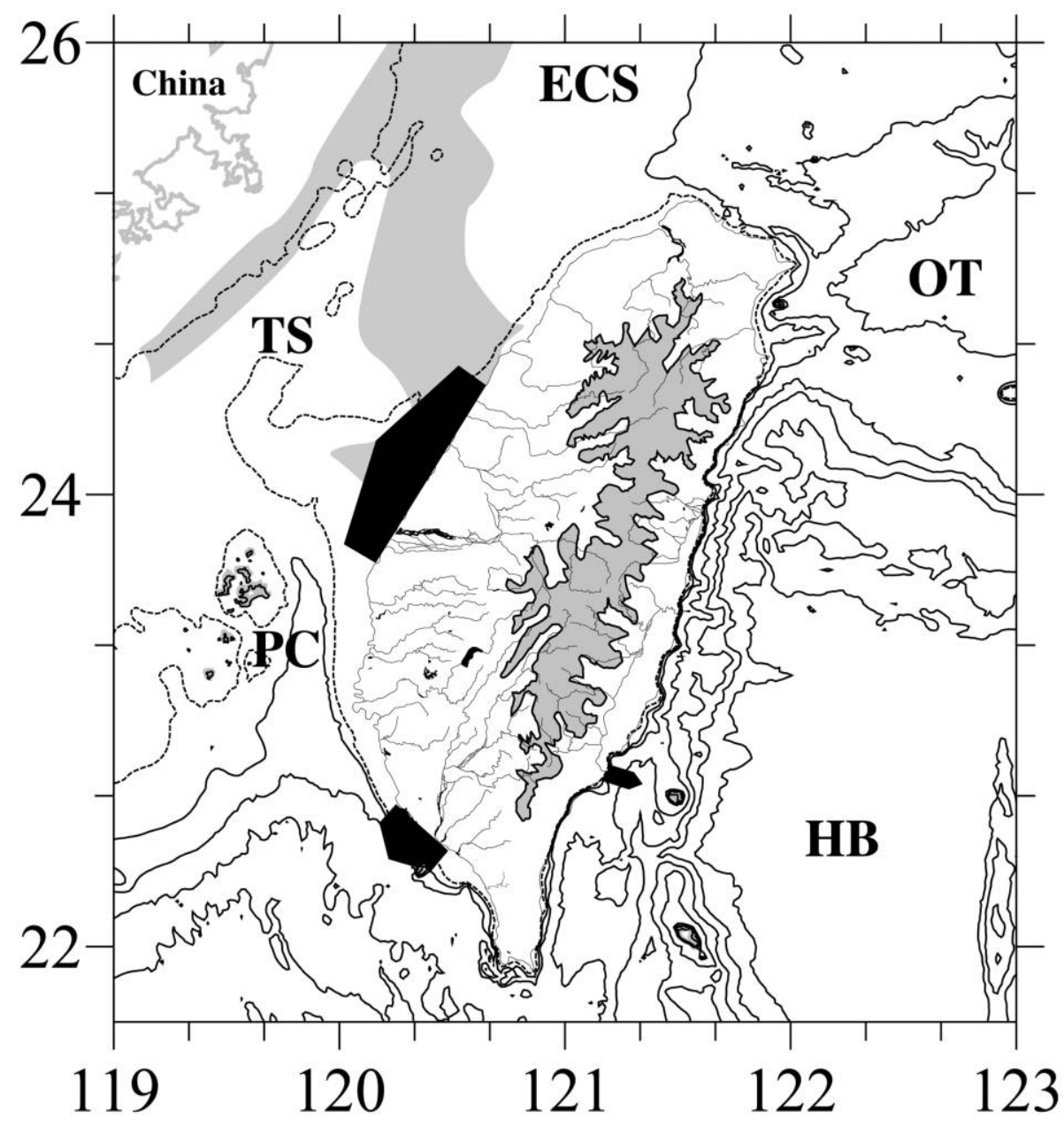

Figure 13. Sediment discharge to the coastal ocean from nine Taiwan rivers following Super-Typhoon Herb, July 31-August 1, 1996. Arrowheads represent $11 \mathrm{MT}$ (southeast), $64 \mathrm{MT}$ (southwest), and $142 \mathrm{MT}$ (northwest), respectively. Bathymetry from Yu and Song (2000). Shelf muds in the Taiwan Strait, defined by $>75 \%$ silt + clay, are derived from Boggs et al. (1979). HT = Huatong Basin; PC = Penghu Canyon; $T S=$ Taiwan Strait; ECS = East China Sea; OT = Okinawa Trough.

More perplexing is the fate of the Herb-derived sediment discharged by rivers north of the structural high that separates the Penghu Canyon from the northern Taiwan Strait (fig. 13). These rivers include not only the Choshui (130 MT of Herbderived sediment, nearly all of it at hyperpycnal levels) but also the $\mathrm{Wu}$, Taan, and Houlong rivers. If the fluvial sediments discharged during Herb and other typhoons (during Typhoon Toraji in 2001, e.g., the Choshui discharged an estimated 175 MT; Dadson et al. 2004) were deposited in the Taiwan Strait, one would expect a thick wedge or wedges of sediment, perhaps evidenced as a prograding delta or clinoform. Yet the Taiwan Strait off central-western Taiwan is dominated by sand, not mud (Boggs et al. 1979; fig. 13), and much of the western coast- line of Taiwan is at present eroding, not accreting. This suggests that much of the sediment entering the coastal waters from these rivers bypasses the littoral zone and escapes to deeper water.

Two fates for the sediment escaping the central and northwestern coast seem particularly plausible: (1) The sediment ultimately passes into the Penghu Canyon system, from whence it ultimately reaches the South China Sea basin. The bathymetric barrier between the northern and central rivers and the Penghu Canyon system, however, makes southward transport unlikely. (2) Most of the eventderived mud is transported northward to a mud patch in the Taiwan Strait (fig. 13) or perhaps farther north into the East China Sea. The northwardflowing Taiwan Warm Current, which achieves 
maximum transport during summer (typhoon) months (Lee and Chao 2003), would seem to be the likely transport agent. The sediment might even be transported around the northern tip of Taiwan and into the Okinawa Trough via the retroflected Taiwan Warm Current (Tseng and Shen 2003), but at present, it seems imprudent to speculate further.

\section{Concluding Statement}

Calculating typhoon-derived sediment concentrations and loads on the basis of so few event-related measurements, as we have done in this article, may give new meaning to the word "speculative." Nevertheless, the close correlation between measured and calculated suspended sediment concentrations (figs. 5-10) indicates that Taiwanese rivers can discharge large quantities of sediment, much of it at hyperpycnal concentrations, during typhooninduced floods. To quantify more accurately the amount and concentration of flood-derived sediment discharged to the coastal ocean during such events, however, will require more frequent measurements during catastrophic events.

The short-term and longer-term fates of the riverderived sediment discharged to the coastal ocean are even less certain. On the basis of bathymetric, geological, and oceanographic considerations, we assume that most of the sediment discharged by southwestern and southeastern rivers during Herb (and other typhoons as well) was transported to deeper water. Sediment discharged by northwest- ern rivers, on the other hand, may have been transported toward the East China Sea. At present, we cannot say whether this sediment escaped the sublittoral cell immediately or was stored temporarily (on the shelf) and subsequently was resuspended and transported away; if the latter case applies, we cannot yet define the processes that would have resuspended and transported the sediment.

Many small rivers throughout the world appear to be event driven in that a large portion of their total sediment load is discharged during relatively few short-lived events. Such rivers include both arid rivers (e.g., Santa Clara) and humid rivers (e.g., Choshui), suggesting that the occurrence of stormrelated hyperpycnal events in other rivers might be more common than is generally believed. Because of their relative frequency and strength, hyperpycnal flows in Taiwanese rivers merit further study if only because they may shed light on processes within other rivers that periodically discharge sediments at hyperpycnal concentrations to the coastal ocean.

\section{A C K N O W L E D G M E N T S}

This study was funded by grants from the U.S. Office of Naval Research and the National Science Foundation. We thank R. Slingerland, N. Hovius, and S. Dadson for helpful discussions during preparation of this article. J. P. M. Syvitski and T. Mulder gave insightful reviews of an earlier draft, for which we are grateful.

\section{RE FER E N C E S C I T E D}

Bates, C. C. 1953. Rational theory of delta formation. Bull. Am. Assoc. Pet. Geol. 37:2119-2162.

Boggs, S., Jr.; Wang, W.-C.; Lewis, F. S.; and Chen, J.-C. 1979. Sediment properties and water characteristics of the Taiwan shelf and slope. Acta Oceanogr. Taiwan. 10:10-49.

Cecil, C. B.; Dulong, F. T.; Harris, R. A.; Cobb, J. A.; Gluskoter, H. G.; and Nugroho, H. 2003. Observations on climate and sediment discharge in selected tropical rivers, Indonesia. SEPM Spec. Publ. 77:29-50.

Chang, J.-C., and Slaymaker, O. 2002. Frequency and spatial distribution of landslides in a mountainous drainage basin: western foothills, Taiwan. Catena 46:285307.

Chen, C.-T. A.; Liu, J. T.; and Tsuang, B.-J. 2004. Islandbased catchment: the Taiwan example. Reg. Environ. Change 4:39-48.

Cohn, T. A. 1995. Recent advances in statistical methods for the estimation of sediment and nutrient transport in rivers. Rev. Geophys. 33:1-18.

Dadson, S. J.; Hovius, N.; Chen, H. G.; Dade, W. B.; Hsieh,
M.-L.; Willett, S. D.; Hu, J.-C.; et al. 2003. Links between erosion, runoff variability and seismicity in the Taiwan orogen. Nature 426:648-651.

Dadson, S. J.; Hovius, N.; Chen, H. G.; Dade, W. B.; Lin, J. C.; Hsu, M.-L.; Lin, C.-W.; et al. 2004. Earthquaketriggered increase in sediment delivery from an active mountain belt. Geology 32:733-736.

Drake, D. E.; Koppack, R. L.; and Fischer, P. J. 1972. Sediment transport on the Santa Barbara-Oxnard shelf, Santa Barbara Channel, California. In Swift, D. J. P.; Duane, D. B.; and Pilkey, O. H., eds. Shelf sediment transport: process and pattern. Stroudsburg, PA, Dowden, Hutchinson, \& Ross, p. 207-231.

Fuller, C. W.; Willet, S. D.; Hovius, N.; and Slingerland, R. 2003. Erosion rates for Taiwan mountain basins: new determinations from suspended sediment records and a stochastic model of their temporal variation. $\mathrm{L}$. Geol. 111:71-87.

Gorsline, D. S. 1996. Depositional events in Santa Monica Basin, California borderland, over the past five centuries. Sediment. Geol. 104:73-88. 
Hartshorn, K.; Hovius, N.; Wade, W. B.; and Slingerland, R. L. 2002. Climate-driven bedrock incision in an active mountain belt. Science 297:2036-2038.

Hicks, D. M.; Gomez, B.; and Trustrum, N. A. 2004. Event suspended sediment characteristics and the generation of hyperpycnal plumes at river mouths: East Coast Continental Margin, North Island, New Zealand. I. Geol. 112:471-485.

Hovius, N.; Stark, C. P.; and Allen, P. A. 1997. Sediment flux from a mountain belt derived by landscape mapping. Geology 25:231-234.

Hovius, N.; Stark, C. P.; Chu, H. T.; and Lin, J. C. 2000. Supply and removal of sediment in a landslidedominated mountain belt: Central Range, Taiwan. I. Geol. 108:73-89.

Hung, J.-J. 1996. Typhoon Herb, the new-central-crossisland-highway and slopeland failures in central Taiwan. Sino-Geotechnics 57:25-30 (in Chinese).

Kao, S. J., and Liu, K. K. 2002. Exacerbation of erosion induced by human perturbation in a typical Oceania watershed: insight from 45 years of hydrological records from the Lanyang-Hisu River, northeastern Taiwan. Global Biogeochem. Cycles 16, doi:10.1029/ $2000 G B 001334$.

Lee, C. T. 1996. A geomorphological view on the disaster in the Chenyulan Creek during Typhoon Herb. SinoGeotechnics 57:17-24.

Lee, H.-J., and Chao, S.-Y. 2003. A climatological description in and around the East China Sea. Deep-Sea Res. Part II Top. Stud. Oceanogr. 50:1065-1084.

Li, Y. H. 1976. Denudation of Taiwan island since the Pleistocene epoch. Geology 4:105-107.

Lin, M.-L.; Jeng, F.-S.; and Wu, C.-C. 1996. Disasters along new central cross-island highway. Sino-Geotechnics 57:31-44 (in Chinese).

Liu, T. K. 1982. Tectonic implications of fission track ages from the Central Range, Taiwan. Geol. Soc. China Proc. 25:22-37.

Milliman, J. D., and Syvitski, J. P. M. 1992. Geomorphic/ tectonic control of sediment discharge to the ocean: the importance of small mountainous rivers. I. Geol. 100:525-544.

Mulder, T., and Syvitski, J. P. M. 1995. Turbidity currents generated at river mouths during exceptional discharges to the world oceans. I. Geol. 103:285-299.
Mulder, T.; Syvitski, J. P. M.; Migeon, S.; Faugere, J.-C.; and Savoye, B. 2003. Marine hyperpycnal flows: initiation, behavior and related deposits: a review. Mar. Pet. Geol. 20:861-882.

Parsons, J. D.; Bush, J. W.; and Syvitski, J. P. M. 2001. Hyperpycnal plume formation from riverine outflows with small sediment concentrations. Sedimentology 48:465-478.

Sommerfield, C. K., and Nittrouer, C. A. 1999. Modern accumulation rates and a sediment budget for the Eel shelf: a flood-dominated depositional environment. Mar. Geol. 154:227-241.

Syvitski, J. P. M. 2003. Predicting the flux of river sediment into estuaries. Estuaries on the edge: convergence of ocean, land, and culture. Estuarine Research Foundation 2003, Seattle, Conference Abstracts, p. 13.

Tseng, R.-S., and Shen, Y.-T. 2003. Lagrangian observations of surface flow patterns in the vicinity of Taiwan. Deep-Sea Res. Part II Top. Stud. Oceanogr. 50: 1107-1115.

Waananen, A. O. 1969. Floods of January and February 1969 in central and southern California. U.S. Geol. Surv. Open File Rep., 223 p.

Waananen, A. O.; Harris, D. D.; and Williams, R. C. 1970. Floods of December 1964 and January 1965 in the far western states. 2. Streamflow and sediment data. U.S. Geol. Surv. Water Supply Pap. 1866-B, 861 p.

Warrick, J. A., and Milliman, J. D. 2003. Hyperpycnal sediment discharge from semi-arid Southern California rivers: implications for coastal sediment budgets. Geology 31:781-784.

WRA (Water Resources Agency). 1992. Hydrological year book of Taiwan: Republic of China, 1990. Taiwan, Ministry of Economic Affairs, 380 p.

1997. Hydrological year book of Taiwan: Republic of China, 1996. Taiwan, Ministry of Economic Affairs, $415 \mathrm{p}$.

Wu, C.-C., and Kuo, Y.-H. 1999. Typhoons affecting Taiwan: current understanding and future challenges. Bull. Am. Meteorol. Soc. 80:67-80.

Yu, H.-S., and Song, G.-S. 2000. Submarine physiographic features in Taiwan region and their geological significance. J. Geol. Soc. China 43:267-286. 